shown working in both Lancashire and water tube boilers. A method of dividing a stream of air-borne coal into two equal streams was illustrated; owing to the unequal distribution of the coal over the crosssection of the pipe when pulverised coal is carried in a stream of air, this equal division has presented difficulties. An ingenious device for estimating the rate of settlement of a suspension of a solid in a viscous liquid was on view. The tube containing the suspension forms part of a pendulum, the change of the period of swing of which is a measure of the rate at which the centre of gravity of the system moves downwards. This apparatus was designed for investigations into the stability of suspensions of coal in oil, but may have other applications.

The experiments in the full-scale horizontal gas retorts, showing the advantages of introducing steam during the last portion of the carbonising period, were of special interest to gas engineers.

\section{Fauna of Indian Salt Lakes}

$\mathrm{I}^{\mathrm{I}}$ EUT.-COL. R. B. SEYMOUR SEWELL has made an interesting study of the fauna of the salt lakes of Calcutta (Rec. Ind. Mus., 36, Part 1. 1934). Recent changes in the general character of some of the rivers in Lower Bengal have had a profound effect on these salt lakes and their associated streams, indirectly influencing the general character of the fauna of certain areas, silting in the rivers and canals due to various causes being the main factor in these changes.

The chief zoological interest in this brackish-water area lies in the fact that it forms one of the main highways by which marine organisms gradually establish themselves in fresh-water. In the neigh. bourhood of the large river estuaries there is a very great amount of available food, both organic and inorganic, and there is a considerable lowering of the salinity in the surface water. The coastal species must be able to withstand a wide variation of salinity, and a further step from brackish- to fresh-water would not be difficult.

The region was almost certainly part of the Bay of Bengal, and with a gradual extension of the delta seawards the water of the rivers and lakes became less salt, but extremely slowly. Both marine forms from the coastal waters and fresh-water species from the rivers would be carried into the salt lakes. There seem to be few instances of a definite attempt at migration upstream from the sea to the fresh-water areas above the influence of the tide.

Although other groups are mentioned and to a certain extent listed, the copepods are studied in the greatest detail. There are true fresh-water forms in the Hooghly River, and in the salt lake with the pools and canals there are normal brackish-water forms; associated with the latter we may get definitely marine forms, a gradual change from freshwater to salt-water species showing in the plankton from the fresh-water of the river system towards the sea.

With regard to the widely distributed Pseudodiaptomus, it is a question whether migration has been from the sea into fresh-water or from freshwater to the sea, or from brackish-water into both regions. The author is of the opinion that it is of marine origin, and that there has been, and still is, a tendency towards migration into brackish- and on into fresh-water.

\section{University and Educational Intelligence}

Cambridge,-Mr. G. H. A. Wilson, Master of Clare College and formerly M.P. for the University, has been elected Vice-Chancellor for the academical year 1935-36.

Dr. W. H. Thorpe, of Jesus College, has been reappointed University lecturer in entomology. Dr. D. H. Barron has been appointed University demonstrator in anatomy.

Miss Dorothy Hill, of Newnham College, has been awarded a Senior Studentship by the Royal Commissioners for the Exhibition of 1851 .

OxFoRD.-Dr. N. V. Sidgwick has been granted the title of professor during the tenure of his readership in chemistry.

Dr. A. H. Gardiner, vice-president of the Egypt Exploration Society and research professor of Egyptology in the University of Chicago, has been elected honorary fellow of the Queen's College.

IN order to encourage research on eugenic problems, and on the genetical and statistical methods needed, if they are to be profitably attacked, the Eugenics Society has decided to provide the funds for a research studentship of $£ 250$ a year, tenable at any of a number of suitable research departments in the United Kingdom. The studentships will bear the name of Leonard Darwin, honorary president of the Society. To make the awards and administer the studentships, an independent committee has been set up with the co-operation of the Royal Society, the Royal Society of Edinburgh, and the Royal Statistical Society. The studentships will be renewable for a second year.

The Social Studies final report of the American Historical Association (Scribner, 1934, pp. 168 , 1.25 dollars) has become one of the chief subjects of educational discussion in America. Dealing as it does with some of the most vital issues of contemporary social life in that country and being, according to one critic, a "daringly realistic" indictment of the present social order, it has, naturally, come in for a good deal of abuse. In School and Society of March 30 appears an address by Prof. Jesse H. Newlon to the American Educational Research Association, in which some of the attacks on it are answered. Among these are complaints of paying lip-service to democratic ideals while knifing them in the back by enlarging on trends towards collectivism, of countenancing the indoctrination of students with subversive ideas, of decrying objective tests and the scientific method generally, of needlessly disparaging existing methods of instruction in teacher-training institutions as mechanical and sterile, of irrelevant eriticism of systems of control and administration of schools. The answers throw much interesting light on current educational practices. Prof. Newlon holds that the scientific method has become a sort of fetisheducational research being concentrated on it as a chief objective in the delusive belief that it can not merely illuminate, but also provide qualitative solutions of problems of educational policy. Summing up the significance of the report, it dares, he says, to make a social analysis and, in harmony therewith, to recommend policies for making education a more effective instrument for social reconstruction. 